\title{
Die profete in huidige Ou-Testamentiese navorsing: tendense en vooruitsigte ${ }^{1}$
}

P A Kruger

\author{
ABSTRACT
}

The prophets in recent Old Testament scholarship: trends and prospects

In this contribution various themes in recent Old Testament prophetic studies are discussed. These include: the title "prophet", the prophets in a sociological-anthropological perspective; the prophets and Israel's religious history, historical and canonical prophecy, and the relationship between the ancient Near Eastern and the Israelite phenomenon of prophecy.

1

INLEIDING

$\mathrm{Na}$ meer as 'n eeu sedert die eintlike aanvang van die moderne wetenskaplike studie van die profete en die enorme hoeveelheid publikasies ${ }^{2}$ wat op die gebied verskyn het (ondersoeke in verband met die profetiese religie, die intellektuele basis van hulle prediking, hulle rol in die geskiedenis en ontwikkeling van Israel se religieuse institusies, studies in verband met hulle literêre nalatenskap: literêrkritiese, vormkritiese en redaksiekritiese studies, die verhouding Ou-Testamentiese en OuNabye Oosterse profesie, moderne sosiologies-antropologiese benaderings ten opsigte van die profete: Carroll ${ }^{3}$ met sy beginsel van "cognitive dissonance"; Wilson ${ }^{4}$ met sy gedagte van "central or peripheral intermediaries"; Petersen 5 met sy idee van "role theory" en Overholt ${ }^{6}$ met sy "cross-cultural perspective"), is daar rede om te glo: nou weet ons min of meer wat 'n profeet is, wat sy rol was ten opsigte van die gemeenskap waarin hy opgetree het en hoe sy profetiese nalatenskap verstaan moet word. As Fohrer in die vroeg-sestiger jare in sy terugskoue op die ontwikkeling in die vyftiger jare die volgende te sê gehad het: "Thus it is possible to view prophecy in a clearer and more comprehensive light than ever before"7, dan behoort ons dertig jaar later met al die nuwe metodes, meer argeologiese en godsdienshistoriese data tot ons beskikking des te meer optimisties te wees om 'n antwoord op die vrae te gee. Maar dit blyk nie die geval te wees nie. Daar is eerder'n groeiende onsekerheid oor wie dié figure nou eintlik was. Die idealisties-romantiese konsepsie wat tot baie onlangs gegeld het, word nie meer so geredelik aanvaar nie. Barstad gaan so ver om te beweer: "Despite the vast amount of literature which has 
increasingly flooded the market, and despite the many valuable insights which have undoubtedly been gained, one rather gets the impression that the study of biblical prophecy a hundred years after its inauguration, can be said to be only in its very beginnings"8. Ander geleerdes, weer, is van mening dat ons afstuur op 'n "paradigm switch"9 met betrckking tot die studie van die Ou-Testamentiese profete. Sommige praat selfs van "The eclipse of the prophet in contemporary prophetic studies"10. Verskillende faktore en ontwikkelings het aanleiding gegee tot die stand van sake. In hierdie bydrae wil ek graag fokus op enkele aspekte wat volgens my oordeel sentraal staan in die huidige debat. Die orde van aanbieding is nie volgens belangrikheid gerangskik nie, maar eerder kronologies, beginnende by die temas wat eerste op die toneel gekom het.

Die betekenis van die veelkantige betiteling "profeet" (Hebreeus: nåbî'), wat ontleen is aan die Griekse woord prophetes, was nog altyd 'n turksvy. Reeds die oudste kommentaar op die Hebreeuse teks, die Griekse vertaling van die Ou Testament, het gepoog om die verskeidenheid van rolle wat met die term năhî' aangedui word te rasionaliseer omdat die vertalers 'n ongemak ondervind het met betrekking tot die wye betekenisspektrum wat die begrip dek. Die ekwivalente prophetes is byvoorbeeld gebruik om benewens nābî', ook nog hozê en ro'ê (beide word gewoonlik met "siener" vertaal) weer te gee. By tien geleenthede word die term nahb̂t ook nader verduidelik met die term pseudoprophetes om die valse profete aan te duil1.

In die vorige eeu was daar by geleerdes geen onsekerheid oor die inhoud van die term profeet nie: "Sprecher, Aussprecher göttlicher Offenbarung"12; "einen lauten klaren Sprecher"13. Hierdie lys het intussen in die twintigste eeu fluks aangegroei: "The prophet is held to be an intensely religious man (Hölscher, Guillaume), a cultic official (Johnson), a social reformer (Weber), a covenant mediator (Kraus, Muilenberg), a messenger (Westermann, Ross), a traditionist (Rohland, Porteous), a man of prophetic consciousness (Buber)"14, maar het tog ook plek gemaak vir meer getemperde uitsprake in die jongste verlede: "...das Nomen (bedeutet)... eher 'Berufener' als 'Sprecher' oder 'Rufender', und seine Ubersetzung mit 'Prophet' ist ein Notbehelf'15.

As 'n mens voorts die Joodse en Christelike beoordelings van profeet en profesie van nader beskou, dan blyk dit dat daar duidelik aksentverskille is ${ }^{16}$. ' $n$ Eerste aanduiding van die verskillende evaluerings is die orde van die Joodse en Christelike kanons wat aan die leser 'n pertinente aanwysing bied hoe die profetiese korpus in die lig van die hele kanon gelees moet word. Die Griekse Ou Testament 
kanon, wat in die Christelike tradisie neerslag gevind het, eindig met die profete. Met dié ordening word die voorspellende aard van die profetiese korpus benadruk: dit wys vooruit na die toekoms. In die Joodse kanon is die profetiese korpus direk naas die wet (tôrâ) geplaas wat onmiddellik aan hulle 'n ander teologiese posisie toeken: hulle is belangrik vir soverre hulle 'n kommentaar op die tôrâ is. Hierdie Joodse oordeel oor die profete kom duidelik tot uitdrukking in die openingsparagraaf van Pirke 'Abot: "Moses received the Torah from Sinai and delivered it to Joshua; then Joshua delivered it to the elders, die elders to the prophets, and the prophets delivered it to the men of the great Assembly". Ook die wyses, wat die profete opgevolg het, is volgens die Joodse konsepsie bewaarders en uitleggers van die tôrâ, wat opgevat word "als die Mitte der Schrift"17. Toegespits geformuleer kan dus gesê word dat dit die Mosaiese tradisie was wat die profete as egte profete gelegitimeer het ${ }^{18}$. Ook nog Luther hou hieraan vas as hy die posisie van die profete op dieselfde wyse uitlê: "Handhaber und Zeugen Moses und seines Amts"19. Dit was eers die geleerdes van die negentiende eeu (Wellhausen en Duhm) wat die profete uit hierdie kanoniese dwangbuis kom bevry het en hulle bestudeer het onafhanklik van hulle kanonieke posisie. Vergelyk die beroemde uitspraak van Duhm in die verband: "Propheten sind die Männer des ewigen Neuen"20.

Wend 'n mens jou tot die Ou-Testamentiese korpus as sodanig, dan blyk dit dat die term profeet met verskillende inhoude gevul was, afhangend van die tydperk en sfeer van toewysing. Bo en behalwe die sogenaamde "skrifprofete" (Jesaja, Jeremia, Esegiël en die Twaalf) en die profete van die monargale periode (Gad, Natan, Abija, ens), is die titel $n a ̄ b \hat{\imath}^{\prime}$ ook honoris causa ${ }^{21}$ aan ander figure toegeken: soos Abraham (Gen 20:7), die patriarge (Ps 105:15), Josua (Jos 6:26; vgl 1 Kon 16:34) en Samuel (1 Sam 3:19vv). Moses was die profeet par excellence (Num $11: 2 ; 12: 2 ; 6-8 ; 13 ; 21: 7$; Deut $18: 15-18 ; 34: 10 ;$ Hos $12: 14)$. Volgens sekere psalmopskrifte was Dawid ook 'n nâb' (2 Sam 23:2; Ps 51:13). Wat al dié figure histories werklik was, is moeilik om te bepaal. Profete in die gewone sin van die woord was hulle egter nie. By die Kronis, weer, wat groot klem plaas op die profetiese dimensie in Israel se geskiedenis, word die "profetiese" lys nog verder uitgebrei22. Dit sluit ook nou figure in soos Jakob, Ehud, Salomo en Jehu. Ook die Levitiese tempelsangers dra die profetiese mantel. In 1 Kronieke 25:1v word hulle taak met die wortel $n b$ ' beskryf. Lang noem die aktiwiteit gepas "prophetisch musizieren"23. Die "ungeheure Lebensfähigkeit" van die profetiese fenomeen wat oor die innerlike potensiaal beskik om "in immer neuem Gewande" sigself te manifesteer, om die woorde van Meyer ${ }^{24}$ te gebruik, hou egter nie hier op nie. Waar die vroeëre profesie "persoonsgebonde" was, ontwikkel daar in die naeksiliese tyd (byvoorbeeld Maleagi en elders) 'n tipe profesie wat "skrifgebonde" is. Hierdie nuwe aard van profesie voltrek sigself in tekste, meer presies in die omgang 
met en interpretasie van tekste 25 . So word "profeet" toenemend "gleichsinnig mit "heiliger Schriftsteller"'26.

Ook in die na-Ou-Testamentiese tyd deurloop die fenomeen profesie ' $n$ eie ontwikkeling. (Vir 'n tipologie daarvan by Qumran, Philo, Josefus en die NuweTestamentiese tyd, vergelyk Aune ${ }^{27}$.) In die moderne tyd ondergaan die begrip selfs nog 'n verdere betekenisverruiming en word dit gebruik om mense met besondere charismatiese gawes aan te dui wat 'n bepalende invloed op die wêreldgeskiedenis gehad het (onder andere Albert Schweitzer, Martin Luther King 28 ). Tereg merk Stolz in die verband op: "In allen Fällen droht ein inflationärer Gebrauch des Begriffs"29.

Wat egter duidelik behoort te wees uit hierdie kort semantiese oorsig van die begrip is dat die volle reikwydte daarvan nie in 'n definisie vasgevang kan word nie. Dis die groot probleem by studies wat hulle met die onderwerp besig hou. Hier kan maar net verwys word na twee resente publikasies ten opsigte van profesie in die Ou Nabye Ooste naamlik as Wilson (1980) na die profete as "religious intermediators" verwys, of as Weippert die profetiese figuur soos volg definieer: "Ein(e) Prophet(in) ist eine Person männlichen oder weiblichen Geschlechts, die (1) in einen kognitiven Erlebnis, einer Vision, einer Audition, einem Traum o.ä., der Offenbarung einer Gottheit oder mehrerer Gottheiten teilhaftig wird, und (2) sich durch die betreffende(n) Gottheit(en) beauftragt weiss, die Offenbarung in sprachlicher oder metasprachlicher Fassung an einen Dritten, den eigentlichen Adressaten, zu übermitteln"30. Dan blyk die beperktheid van so 'n definisie duidelik omdat dit nie omvangryk genoeg is om die kaleidoskopiese aard van die Ou-Nabye Oosterse fenomeen (Israel ingesluit) semanties, ideologies en kronologies te beskryf nie. Dit ruim, byvoorbeeld, geen plek in vir die latere Ou-Teslamentiese ontwikkeling van "skrifinterpretasie"31 nie. 'n Verdere probleem is of so 'n algemene definisie betrekking het op kanoniese of historiese profesie omdat daar, wat die Ou-Testamentiese gegewens betref, 'n onderskeid is (kyk die paragraaf oor "Kanoniese en historiese profesie"). In stede daarvan om die begrip nahi' netjies in 'n definisie in te pas, is dit nodig dat weer ag geslaan sal moet word op 'n uitspraak wat Fascher reeds in 1927 gemaak het in 'n terminologiese ondersoek van die Griekse term prophetes: "prophetes ist ein 'Rahmenwort' ohne konkreten Inhalt"32.

Uitgaande van die gedagte van 'n "Rahmenwort" moet telkens gepoog word om vas te stel waarop die betiteling "profeet" in 'n gegewe Ou-Testamentiese konteks slaan. Hier kan breedweg een van twee weë gevolg word, wat sal afhang hoedanig die ondersoeker die bronne evalueer. Daar kan argumenteer word dat die profetiese titel 'n skepping is van die tradente of redaktore. Dit is onder andere die standpunt van Rendtorff wat van mening is: "Die Quellen lassen oft keine sicheren historischen Schlüsse zu. Man kann häufig nur feststellen, welches Bild die 
Überlieferung an bestimmten Punkten von Propheten hat..."33 Of die ietwat meer ekstreme oordeel van Carroll wat beweer: "It is in the redaction and receptionhistory of texts that the prophets exist"34. Of mens kan jou stel op die standpunt van Jeremias (1988) wat toegee dat die profetiese tekste, soos ons dit nou in 'n eindgestalte in die Hebreeuse Bybel het, die stempel van die latere tradente dra, maar dat 'n versigtige "Rücktasten" in die oorlewering ons tog toelaat om 'n voorstelling te maak van 'n gegewe profeet se profetiese selfverstaan: "Viel zu wenig reflektiert ist demgegenüber die Tatsache, dass wir das Selbstverständnis der klassischen Propheten den überkommenen Prophetentexten keineswegs unmittelbar entnehmen, sondern allenfalls in mühsamer redaktions- und überlieferungskritischen Analyse rekonstruieren können"35. In so ' $n$ "terugtasting" sal 'n ondersoeker egter daarvoor moet waak dat hy nie sy semantiese net so wyd span dat hy die besondere ten koste van die algemene uit die oog verloor, of dat hy eers self besluit wat ' $n$ nabî is en dan die gegewe getuienis in terme daarvan beoordeel nie. Dit is, byvoorbeeld, die gevaar wat bestaan in die benadering van die 1973 "Seminar on Early Christian Prophecy" van die SBL wat die volgende definisie van die term "profeet" in die Nuwe Testament aanvaar het: "The early Christian prophet was an immediately-inspired spokesperson for God, the risen Jesus, or the Spirit who received intelligible oracles that he or she felt impelled to deliver to the Christian community or, representing the community, to the general public" 36 . Veeleer moet elke tekskorpus (of dit 'n boek of 'n groep van boeke is) as 'n geslote literêre eenheid behandel word. Daar moet noukeurig gelet word op die sosiologiese of ideologiese gesigshoek van waaruit die betiteling "profeet" toegeken word. Dit kan selfs wees dat die persepsie omtrent profeetwees binne een boek, wat die naam van 'n gegewe profeet dra, verskillend interpreteer kan word. Hier kan verwys word na die enigste gebore en getoë "skrifprofeet" van die Noordryk, Hosea. Dit wil voorkom of die benaming profeet wat by verskillende geleenthede gebruik word $(4: 5 ; 6: 5 ; 9: 7-8 ; 12: 11,14)$, uit verskillende ideologiese hoeke ontspring: die profeet se eie persepsie oor die aard van sy amp (9:7-8); die oordeel van sy dissipels (6:5) en die van latere (deuteronomistiese?) tradente $(12: 11,14)$.

Helderheid oor die etiket "profeet" is nie net vir die Bybelwetenskap van belang nie, maar het ook konsekwensies vir die veelbesproke profetiese taak van die kerk. Word die Joodse kanon, byvoorbeeld, as uitgangspunt geneem, dan lê die profetiese taak in die verlengde van tôrâ-uitleg, met ander woorde die profeet as skrifgeleerde. Geld die Christelike kanon as vertrekpunt, dan is die aksent op die voorseggende element. Grond die uitlegger hom op die gerekonstrueerde profetebeeld van die kritiese Bybeleksegese, dan is die profeet in sy wese 'n sosiale hervormer, of om dit in die woorde van Barton uit te druk: "When Christian writers and church leaders speak of the prophetic role of the Church or its members, they 
are nearly always referring consciously to the distinguishing marks of "classical" prophecy as reconstructed by a century of biblical criticism. In modern Christian usage, to call someone a prophet is generally to imply that he has something to say that poses a challenge to a complacent world" ${ }^{37}$. Te lank het die kritiese Bybelwetenskap alleen die kontoere van die profetiese taak van die kerk bepaal. Die skewe gestalte wat dié opdrag gevind het in die vryheidsteologie is in die lig hiervan heeltemal te verstane: "Für Theologen der Befreiung ist das Prophetische eine Totalkategorie der Bibel... Daher ist Prophetie ein Synonym für Befreiung"38. So 'n opvatting sou 'n growwe verskraling beteken. Die "profetiese" taak van die kerk moet in 'n veel wyer perspektief gesien word en die aard van 'n gegewe tydsgewrig sal baie maal bepaal watter profetiese kwaliteite van toepassing is. Een moontlikheid sou wees om dit soos Brueggemann te begryp wat heel gepas sê dat die "prophetic consciousness" 'n "alternative consciousness" beliggaam. Hierdie "alternative consciousness" kan dien om die onderdrukkende magte in die samelewing te kritiseer (criticise) of om die geloofsgemeenskap op te roep en te versterk (energize) om nuwe vergesigte van geregtigheid, deernis en gelykheid te visualiseer ${ }^{39}$. Die profetiese taak van die kerk (of miskien moet mens praat van die profetiese take van die kerk) kan daarom nie onder een noemer tuisgebring word nie. Die een oomblik sal dit daarin moet bestaan om onderdrukkende en onregverdige strukture te kritiseer (in lyn met die opvatting in die kritiese Bybelwetenskap), die ander oomblik sal dit etiese perspektief wat gerig is op die herstel van menswaardigheid, bemoediging (soos in die Joodse kanon) en 'n toekomsvisie (volgens die Christelike tradisie) voorrang moet kry. Soms sal dit eenvoudig net daarin bestaan om die regte tyd te ken, soos Barth sê: "Kein Tun der Staatsmänner und die Völker ... Techniker und Feldherren irgendeiner Zeit kann gründlicher zeitlich sein als das Tun der christlichen Gemeinde, wenn sie in ihrem Dienste tätig ist. Und eben sofern es in diesem gründlichen Sinn zeitlich ist, wird es prophetisch"40.

\section{DIE PROFETE IN SOSIOLOGIES-ANTROPOLOGIESE PERSPEKTIEF}

Terwyl die fokus van publikasies oor die profete tot 'n dekade gelede nog byna uitsluitlik op die aard van die profetiese prediking en 'n analise van die literatuur wat dit produseer het, was, word daar toenemend meer aandag gegee aan, wat Gottwald noem, "sociological exegesis": "The social science paradigm shifts attention from the history and religion by concentrating on the Hebrew Bible as a residue of social worlds in which real people lived in social networks and fought out social struggles that were highly influential in the environment of the biblical writers and 
which are attested in social data and allusions in biblical texts"41. Die idealistiese profetebeeld wat in die negentiende eeu en tot baie onlangs gegeld het (weer in die woorde van Gottwald 42 "lone critics... great men who made history"), maak al hoe meer plek vir 'n profetiese figuur wat nie los staan van sy gemeenskap nie, maar intiem sosiologies daarmee verweef is. Die sosiologiese komponent in die profetiese eksegese is niks nuut nie, maar het reeds vroeg in die twintigste eeu, met die geboorte van die vormkritiese benadering (Gunkel), aandag gekry. Egter nie om die sosiale gesitueerdheid ("social location") van die profetiese figur te bepaal nie, maar om die tipe literatuur te verstaan wat ten gevolge van die spesifieke sosiale milieu voortgebring is ${ }^{43}$. Die eintlike impetus tot 'n sosiologiese benadering van die Ou-Testamentiese profete het gekom van kollegas op die gebied van die antropologie (byvoorbeeld Evans-Pritchard en Lewis) wat in ander kulture (veral Afrika) die sosiaal stabiliserende of destabiliserende rol van die profetiese figuur (of shamaan of religieuse middelaars soos hulle ook genoem word) bestudeer het ${ }^{44}$. Evans-Pritchard en Lewis het duidelik aangetoon dat profetisme nie 'n suiwer religieuse verskynsel is nie, maar dat by die verstaan daarvan deeglik kennis geneem moet word van die sosiologiese milieu wat tot die opkoms daarvan aanleiding gee. Burridge gaan so ver om die interaksie soos volg te beskryf: "He (i.e. the prophetic figure) must articulate thoughts and aspirations and emotions, that are immanent in the community to which he speaks if he is to be accepted as a prophet" 45 . Hierdie insigte is deur Ou-Testamentici opgevolg. Wilson ${ }^{46}$ wys byvoorbeeld daarop dat 'n profeet alleen kan funksioneer as hy kan staatmaak op 'n ondersteuningsgroep ("support group"). Overholt steek in sy transkulturele werk 47 lig op by die Indiaanse beskawing en fokus op die interaksie tussen die profetiese figuur en sy hoorders. In die benadering is die klem nie soseer op die "profetiese" boodskap as sodanig nie, maar op die sosiale prosesse wat "profesie" produseer. Die sosiologies-antropologiese benadering het daarom beslis die ondersoeker sensitief gemaak vir die sosiale verwikkeldheid van die profetiese figuur, maar soos met enige nuwe benadering, het dit ook sy eie toepassingsprobleme meegebring:

i) Subjektiewe keuses en die ondersoeker se (soms gebrekkige en onvoldoende) verstaan van 'n gegewe sosiologiese model wat gebruik word, is bepalend vir die resultaat van so 'n ondersoek. Hoe subjektief so 'n onderneming baie keer kan wees, word goed saamgevat deur Carroll: "One cannot help but be struck by the differences that exist between Weber's solitary demagogues, Petersen's neatly packaged central morality prophets and Lang's socially well-placed spokesman for the nobility and how far removed these all are from the thundering denouncers of justice envisioned by some non-western theologians" 48 .

ii) Die bruikbaarheid van die benadering met betrekking tot Bybelse gegewens word bemoeilik omdat die wetenskappe van die sosiologie en antropolo- 
gie met empiriese data van kontemporêre gemeenskappe werk. Rodd sê: "...there is a world of difference between sociology applied to contemporary society, where the researcher can test his theories against evidence which he collects, and historical sociology where he has only fossilized evidence that has been preserved by chance or for purposes very different from that of the sociologist"49.

iii) 'n Ander probleem in dié verband is die dateerbaarheid van die Bybelse Hebreeuse bronne wat aan so 'n sosiologiese analise onderwerp moet word. Om 'n voorstelling te probeer maak van die sosiologiese milieu van 'n gegewe profeet moet die ondersoeker beskik oor getuienis wat teruggaan op so 'n historiese figuur. Hier kan mens maar net kyk na die onlangse verskillende evaluerings van Amos deur Fleischer ${ }^{50}$ en Kessler 51 . Tot tyd en wyl daar nie meer sekerheid verkry is oor die omvang van historiese profesie nie, kan nie veel hulp van die sosiologiese benadering verwag word nie.

iv) 'n Verdere problematiese aspek wat 'n sosiologiese analise van Bybelse profetiese tekste bemoeilik is die ideologiese perspektief van waaruit die tekste tot stand gekom het. Wat hier onthou moet word is dat die eerste sogenaamde "skrifprofete" (die van die agste eeu) nie in die eerste plek skrywers was nie, maar sprekers (Gunkel). Dit beteken dat die finale opskrifstelling van hulle uitsprake nie op hulle rekening geplaas kan word nie, maar teruggaan op dié van hulle volgelinge. Dit is dan ook vandag die groot twispunt in profetiese navorsing: wat is primêr en wat is sekondêr? So 'n onderskeid is egter van fundamentele belang ten opsigte van die rekonstruksie van die sosiologies-antropologiese en ideologiese omstandighede waarin 'n gegewe profeet sy taak uitgevoer het. As daar dan, soos sommige geleerdes beweer, 'n paradigmaverskuiwing ten opsigte van die sosiologiese verstaan van die profete in die algemeen is, dan is dit belangrik om te vra watter tekskorpus gebruik word om as basis van so 'n tese te dien. Die uitspraak van Carroll met betrekking tot die sosiologiese benadering van die profete mag radikaal klink, maar sy volgende opmerking verdien ernstige besinning: "In the matter of the prophets we have to abandon the socio-historical approach because the biblical text is too ideologically compromised to afford us any objective data" 52 .

v) Sosiologiese modelle werk met stereotipes en die universaliteit van 'n spesifieke sosiale orde. Wat die profete betref, beteken dit dat "a prophet can be located on a social grid" en dat dié sosiale ordening "provides the modern reader with a deeper insight into his self-consciousness ${ }^{53}$. Hierdie konsentrasie op die "social structure", soos Hobbes dit noem 54 met verwysing na Petersen se sosiale plasing van die profete (1981), laat volgens eersgenoemde nie genoeg ruimte vir profetiese individualiteit nie. In die verband kan ook verwys word na Herion se kritiek (1986) op Wilson (1980). Hy verwerp die tese van Wilson dat 'n profetiese figuur alleen kan funksioneer as hy 'n ondersteuningsgroep het. Dit sou inhou dat 
so 'n figuur gereduseer word tot 'n blote verlengstuk van sy "support group": "In this view, the prophet's autonomy and individuality essentially have been stripped from him: his personal convictions, values and beliefs are either non-existent... or more simply they are reflective of his particular ... group's interest"55. Hoe 'n mens ookal die sosiologiese posisie van die profetiese figuur definieer, die herstel van sy individualiteit (of charisma, soos Weber dit noem) sal 'n belangrike opgaaf van toekomstige profetiese navorsing moet wees.

PROFESIE EN GODSDIENSHISTORIE

Samelopend met tendense in die nuwere profetiese navorsing wat na die profetiese fenomeen vanuit 'n sosiologiese gesigshoek kyk, was daar in die afgelope jare ook veel en interessante beweging op die gebied van godsdiensgeskiedenis van Israel. Dat die religie van Israel 'n "gewordene"56 grootheid is, word allerweë aanvaar. Hoe hierdie "gewordenheid" egter tot stand gekom het, daaroor is daar nie ooreenstemming nie. Veral twee sake staan hier in die sentrum van diskussie: (a) die verband tussen die Israelitiese kultuur en die wyer Ou-Nabye Oosterse wêreld, en (b) wat Israel spesifiek betref: die ouderdom van die monoteïsme en die bydrae van die verskillende kragte/instellings (monargie, priesters, profete) in die totstandkoming daarvan. Wat dié aspekte betref, was daar in die religiegeskiedenisse tot en met die sestiger jare ${ }^{57}$ nog die voorstelling dat die Israelitiese religie geïsoleerd ontwikkel het en dat die monoteïsme 'n vroeëre verskynsel was. Die infiltrering van die Kanaänitiese gedagterigtings op hierdie eens suiwere Jahwisme was die belangrikste rede tot religieuse afvalligheid. Die taak van die klassieke profete het ten gevolge hiervan daarin bestaan om die volk terug te roep tot die oorspronklike religieuse toestand. Dieselfde idee het ook in die godsdiensgeskiedenisse van die negentiende eeu geheers, hoewel hulle die ontwikkeling op 'n evolusionistiese wyse verklaar het en die profete se bydrae dan dienooreenstemmend evalueer is. Vergelyk hier veral Vatke wat in die profete van die agste eeu die hoogtepunt sien van die dialektiese proses wat reeds by Moses begin het: teenoor die nasionale- en natuurreligie van die volk het hulle (dit is die profete) vir die eerste keer "die universalistische Gottesanschauung und Idee der Teokratie entscheidend ausgebildet" 58 .

Hierdie tradisionele voorstelling het plek gemaak vir 'n redelik radikale aksentverskuiwing in die jongste verlede ten opsigte van die verloop van dié proses. Die nuwe persepsie het deels tot stand gekom op grond van inligting uit inskripsies soos Kuntillet Ajrud en Kirbet el-Qom: die vroeë Israelitiese religie het ontwikke] uit 'n oorspronklike Kanaänitiese matriks 59 en het geleidelik van 'n politeïsme gegroei na teoretiese monoteisme in die eksiliese periode. Die voorstelling word 
wyd deur geleerdes aanvaar en het belangrike implikasies vir die rekonstruksie van die Israelitiese religiegeskiedenis. Lohfink som hierdie nuwe tese goed op as hy die volgende sê in 'n bespreking van die nuutste religiegeskiedenisse (De Moor, The rise of Yahwism, 1990; Niehr, Der höchste Gott, 1990 en Smith, The early history of God, 1990): "Vor allem ist es die Ablehnung der früher gängigen Auffassung, daß die Jahwereligion zuerst eine Grösse gewesen und dann in einer zweiten Phase gewissermassen von aussen in eine Beziehung der Attraktion und Gegnerschaft zugleich zur kanaanäischen Religion getreten sei. Das bedeutet zunächst einmal, daß man gewissermassen die polytheistiche Grundingredienz des biblischen Monotheismus stärker beachten müsste" 60 . Dit beteken voorts dat daar in die lig hiervan veral 'n herwaardering gemaak sal moet word met betrekking tot (i) die herkoms van die Jahwisme, met ander woorde watter faktore (religieus, polities, ens) daartoe aanleiding gegee het dat Jahwe tot "der höchste Gott" (Niehr) in beide die ryke van Israel en Juda geraak het; hoe hierdie ontwikkeling religieus-histories voorgestel moet word en uit watter tyd dit dateer? (ii) In noue samehang hiermee sal ook meer duidelikheid verkry moet word oor die herkoms en ouderdom van die monoteïsme. Dat hierdie aspek nog ver van 'n konsensus is, kan duidelik gesien word in die maksimalistiese en minimalistiese benaderings van onderskeidelik De Moor en Smith. (iii) In die nuwe religie-geskiedenisse word daar ook baie meer gemaak van die verskillende vlakke waarop die religieuse belewing in Israel tot uitdrukking gekom het en die onderskeide wat daar tussen die verskillende vlakke bestaan het ten opsigte van uitdrukkingsvorme.

Waar Albertz, wat verantwoordelik is vir die mees resente religiegeskiedenis van Israel op grond van skriftelike bronne, nog in sy Persönliche Frömmigkeit und offizielle Religion (1978) net twee vlakke onderskei het (te wete die persoonlike- of familie-religie en die offisiële religie), brei hy dit in sy onlangse Religionsgeschichte Israels in alttestamentlicher Zeit (1992) uit tot drie vlakke (die lokale religie word bygevoeg). Hy gaan voort om daarop te wys dat selfs dié onderskeidings ook nog te simplisties is en dat ook dit nie genoegsaam uitdrukking verleen aan die veelkantigheid van die religie nie: "Das Hauptstratum der auf das Volk bezogenen 'offiziellen Religion' ist nun aber wiederum keine monolitische Einheit, genauso wenig wie die israelitische Gesellschaft eine solche Einheit bildete. Neben die Funktionsträger der religiösen und politischen Institutionen, die Priesterschaften der verschiedenen Heiligtümer, die Ältesten und das Königshaus... traten religiöse und politische Oppositions- und Reformgruppe wie die Propheten oder Deuteronomiker, welche den vorgefundenen Ausprägungen der offiziellen Jahwereligion die Legitimation absprachen und ganz neue theologische und kultpolitische Konzeptionen entwickelten"61. In die lig hiervan sal daarom weer opnuut gekyk moet word na die samehang en verskille tussen die verskillende vlakke. (iv) Opvallend is ook die sentrale posisie 
wat in die nuwe konsepsie ingeruim word vir die profete: hulle is die eintlike impetus agter die vestiging van 'n "Jahwe-alleen beweging"62 in die 9de-8ste eeu. Die sosiologiese en religieuse faktore wat egter aanleiding gegee het tot die opkoms van die rigting, daaroor bestaan daar egter nog nie eenstemmigheid nie. (v) By die ryke oes van publikasies oor die godsdiensgeskiedenis van Israel in 1990, het daar in 1992 ook nog 'n ander publikasie bygekom wat in die jare wat kom 'n bepalende invloed sal hê op die religieuse voorstelling van die monargale en pre-monargale periode. Die publikasie waarna verwys word, is die van Keel-Uehlinger, Göttinen, Götten und Gottessymbole ${ }^{63}$, wat die godsdiensgeskiedenis van Israel rekonstrueer op grond van nie-skriftelike (ikonografiese) bronne. Party van die afleidings wat in die studie gemaak word, wyk reëlreg af van sommige konsepsies wat op grond van skriftelike bronne gemaak is. Dat die studie daarom 'n belangrike bykomstige (of laat mens liewer sê: 'n eiesoortige en unieke) en welkome bron sal wees vir die nuwe geslag godsdienshistorici, is sonder twyfel.

'n Ander problematiese aspek wat in die Ou-Testamentiese wetenskap reeds 'n lang tyd al aangevoel is, maar wat eers weer in die resente tyd sterk op die voorgrond gekom het, is die hele kwessie van historiese en kanoniese profesie. Waar begin die een en waar hou die ander een op? Wat is die verskil tussen die twee en hoe moet dit beoordeel word? Belangrik is dit om te besef dat die profetebeeld wat in die Ou Testament aangebied word, 'n kanoniese waardering van profesie is, met anderwoorde, dit wat as die ideaal gestel is. Hiervolgens is 'n profeet iemand wat staan in die successio Mosaica. Hy is charismaties en persoonlik deur Jahwe geroep en op grond waarvan hy 'n verkondiger word van 'n Goddelike boodskap wat in die eerste plek bedoel is vir die hoorders van sy dag64. Wat ons egter nie weet nie is "... wo das historische Phänomen aufhört und die Interpretation beginnt, wieweit sie einander durchdringen, wieviel die Interpretation vom vielfältigen historischen Erscheinungsbild verschweigt" 65 . Die wyse hoe die vraag beantwoord gaan word, sal afhang hoe die profetiese bronne waarmee gewerk word, beoordeel word. Hulle kan uit die staanspoor bevraagteken word as historiese dokumente ("... they were by no means witnesses to the truth" 66 ) en as tendensieuse geskrifte beskou word. Daarmee word aanvaar dat die historiese profeet so diep verborge lê onder die kanoniese profeet dat dit 'n hopelose saak is om eersgenoemde bloot te lê. Waarmee die ondersoeker (en Ou Testament teoloog) in die Ou-Testament daarom gekonfronteer word, is die "'Präsentation' der Propheten ... d.h. mit der Darstellung der Propheten, wie sie die Autoren der Bibel in ihrer kanonischen Gestalt den Lesern spăterer Generationen weiter geben wollten"67. Daar is dus volgens die benadering 'n beweging weg van 
die historiese figuur na die oorlewering wat sy naam dra. Dit gaan nie meer primêr om die vasstelling van dit wat "eg" en "oneg" is nie, maar om die literêr en teologiese oorwegings wat aanleiding gegee het tot die groei van 'n profetiese boek ${ }^{68}$. So 'n verskuiwing weg van die historiese na die redaksiehistoriese figuur het natuurlik implikasies omdat die outoriteit van die bronne, wat voorgee dat hulle histories is, daarmee in gedrang kom. ' $n$ Mens kan weer eens net na resente studies oor die boek Hosea kyk om te sien hoe hierdie verskuiwing weg van die historiese na die redaksiehistoriese profeet sigself voltrek. Die eerste studie is die van Nissinen (1991) wat handel oor die wordingsproses (of soos hy dit noem "Fortschreibung") van twee hoofstukke (vier en elf) in die boek Hosea. Na afhandeling van sy analise waarin alleen enkele verse aan die historiese Hosea toegeskryf word, maak hy die volgende afleiding oor die profetebeeld wat in die boek tot uitdrukking kom: "Vergleichen wir dieses Ergebnis mit den bisherigen Hoseainterpretationen, so stellt sich sofort heraus, dass die Entstehung des Hoseabuches hier als viel komplizierter erscheint als man allgemeinhin gedacht hat. Nicht nur ist die Zahl der am Werdeprozess beteiligten Hände gestiegen, auch die Persönlichkeit des Propheten Hosea, die bislang eine wichtige Rolle gespielt hat, ist so gut wie aus dem Blickfeld verschwunden" 69 . So 'n gerekonstrueerde profetebeeld het op sy beurt weer implikasies vir 'n voorstelling van die godsdiensgeskiedenis van Israel in hierdie kritieke oorgangsfase omdat Hosea tot nou as 'n tipe Archimedespunt gegeld het in die verband. Daarteenoor staan die meer konserwatiewe redaksiehistoriese benadering van Naumann (1991) in die Von Rad-Wolff-Jeremias-tradisie wat aan die historiese Hosea veel meer materiaal toeken as aan die kanoniese Hosea. Hy sluit sy studie af met die volgende resultaat: "Die Untersuchung von Hos 4-14 unter nachinterpretarischen Gesichtspunkten hat gezeigt, dass der Text erstaunlich wenig bearbeitet wurde. Spätere Tradenten haben das Hoseabuch nicht wesentlich verändert"70. Die profetiese voorstelling wat ons dus in die boek verneem is eg Hoseaans.

Hoe die volgende hoofstuk in hierdie opsig met betrekking tot die profetiese navorsing daar sal uitsien, moet afgewag word. Die pendulun is op die oomblik besig om te ver na die een kant (die redaksiehistoriese) te swaai. Soos Gunneweg sê: "Die Wahrheit dürfte in diesem Fall in der Mitte liegen"71, met ander woorde, iewers tussen die historiese en kanoniese profesie. Miskien is dit raadsaam om in die verband ook weer lig op te steek by die ou meesters wat dieselfde probleme ervaar het in verband met die betroubaarheid van die oorlewering. Vergelyk hier die wyse opmerking van Budde in 1900 wat sê: "... dass die Überlieferung in zahllosen Fällen echte Geschichte in Formen kleidet, die auf den ersten Blick gar keinen Vertrauen zu verdienen scheinen. Die Aufgabe des wahren Historikers ist zunächst, die Überlieferung zu verstehen. Die richtig verstandene 
wird es nicht wegwerfen, sondern an der richtigen Stelle verwerten. So wird aus Uberlieferung Geschichte"72.

\section{DIE VERBAND TUSSEN DIE OU-NABYE OOSTERSE EN ISRAELITIESE PROFESIE}

Die nuwere tendense in die studie van die Ou-Testamentiese profete het geleerdes ook weer met ander oë na vergelykbare verskynsels in die wyere Ou Nabye Ooste laat $\mathrm{kyk}^{73}$. Die idee is egter nie hier om 'n oorsig te gee van die geskiedenis van navorsing op die gebied nie ${ }^{74}$, maar om alleen enkele opmerkings te maak oor temas in die verband wat direk aansluiting vind by dit wat in die voorafgaande paragrawe bespreek is.

i) 'n Belangrike aspek wat reeds met die ontdekking van die "profetiese" tekste omstrede was, maar wat nou ook weer in die nuwere navorsing sterk na vore kom, het te make met die toepaslikheid van die term "profesie" op hierdie vergelykbare Ou-Nabye Oosterse verskynsels (sien paragraaf 2 bo). Omdat, soos aangedui is, die betiteling profeet in die Ou Testament teologies en ideologies gekleur is, kan die waarskuwing van Ellis goed begryp word: "We must also attempt to avoid imposing on the source (i e sekere Akkadiese tekste) value judgments conditioned by our own religious beliefs or those of our heritage"75. Wat as profeties geld, hang ook ten opsigte van die Ou-Nabye Oosterse tekste af van die tipe definisie waarmee die ondersoeker hom bedien. Dit het dan ook gebeur dat verskillende tekste as "profeties" geklassifiseer is wat nie daarvoor kwalifiseer het nie ${ }^{76}$. Wat hier belangrik is, is dat onthou moet word dat die mens van die $\mathrm{Ou}$ Nabye Ooste op twee maniere toegang tot die wil van die godheid verkry het: op 'n induktiewe (deur gebruikmaking van tegniese middele soos die stand van hemelliggame, bewegings van verskillende diere, hidromantie, ens.) en intuitiewe wyse (direk, sonder die tussenkoms van die middele ${ }^{77}$. Wat die Ou Nabye Ooste betref, was eersgenoemde die reël, terwyl laasgenoemde (dit is intuitiewe profesie) 'n marginale verskynsel was. In die Ou Testament is dit presies die teenoorgestelde geval: induktiewe mantiek het beslis wyd bestaan hoewel dit meestal verswyg word, terwyl die intuitiewe die eintlike "wettige" toegang tot die Godskennis was. Bo is daarna verwys dat die Ou-Testamentiese profesie baie gesigte gehad het en dat dit daarom onmoontlik is om dit onder een gemene deler tuis te bring. Die tipering sal afhang van die tipe literatuur en die tydperk. Die definisie van Weippert ten opsigte van die Ou-Nabye Oosterse profesie waarna bo verwys is en wat die volgende komponente bevat: 'n godheid wat deur middel van 'n openbaring (of op dergelyke wyse) ' $n$ boodskap aan ' $n$ tweede persoon deurgee en so iemand wat hom daartoe verplig voel om dit aan 'n derde oor te dra, is weliswaar ook van toepassing op die 
Ou-Testamentiese profete van 'n gegewe tyd (bv hofprofete soos Natan en Gad), maar is nie bruikbaar vir die tipe "skrifprofesie" wat in 'n later tyd in swang was nie. Terminologies is daar dus grense en 'n ondersoeker moet duidelik te kenne gee met watter definisie van profesie hy werk. 'n Gegewenheid wat egter in die nuutste navorsing weer sterk beklemtoon word is dat Israel ten opsigte van die verskynsel profesie (soos dit byvoorbeeld tot uitdrukking kom in die sg hofprofesie) volledig deel was van die Ou Nabye Ooste. Israelitiese profesie is nie, soos in sommige kringe geglo word, 'n uniforme en probleemlose grootheid teenoor die bonte spektrum van die wyere Ou-Nabye Oosterse divinasie nie ${ }^{78}$. Die interafhanklikheid in die geval word in onlangse gegewens ook nog verder bevestig. Die Hebreeuse term $n a \hat{b} \hat{\imath}$ ', waarvan die etimilogie geleerdes so lank ontwyk het, het ook nou 'n parallel gevind in die Akkadiese "profetiese" titel $n \hat{a} b \hat{u}$ wat in 'n resent-gepubliseerde Mariteks voorkom ${ }^{79}$. Die funksie van die betiteling is nog onseker; dit kan te doen hê met divinasie 80 .

ii) Die appél op die realiteit van die Ou-Nabye Oosterse profetiese verskynsel hou verder verband met die tema wat in paragraaf 4 bo aangespreek is. Daar is verwys na die redaksiehistoriese verskuiwing in die huidige navorsing: die lig val op die gevormde literêre produk terwyl die historiese profeet heeltemal uit die blikveld verdwyn. Die profeet word daarmee 'n konstruksie van die redaksie. Dis teen die rigting, wat reeds deur Kaiser in die vyfde uitgawe van sy Jesajakommentaar ${ }^{81}$ begin is, dat Ringgren hom in sy artikel (1986) met die titel "Israelite Prophecy: Fact or Fiction?", rig. As, so beweer hy, "all attempts at a historical, sociological, or psychological interpretation of O.T. prophetism based on the Deuteronomistic history work and the scriptural prophets turn out to be worthless" 82 , dan bly een van die bewyse om nog aan die werklikheid van dié figure in Israel vas te hou die beroep op die bestaan van vergelykbare religieuse fenomene by hulle bure.

iii) Sedert die ontdekking van die eerste "profetiese" tekste 'n honderd jaar gelede word nog steeds gevra na die unieke in die Israelitiese profesie in die lig van die Ou Nabye Ooste. Dit des te meer soos tekstuele getuienis aangroei, want "Je mehr wir über das nichtisraelitische Prophetentum im alten Vorderen Orient erfahren, desto bunter wird das Bild ihres Wirkens, aber auch desto komplizierter die Fragestellung nach Bezügen und Berührungen zwischen ihnen und den Propheten des Alten Testaments"83. Dit beteken dat die antwoord op die vraag voortdurend in die lig van nuwere inligting herwaardeer moet word. So het die "profetiese" korpus uit Mari van 27 (28) waarop onder andere Noort ${ }^{84}$, Malamat ${ }^{85}$ en Weippert ${ }^{86}$ hulle bevindinge baseer het intussen met die publikasie van Durand 87 tot ongeveer 50 aangegroei. Ook wys die publikasie van een van die nuwere "profetiese" tekste dat verspreiding van die profetiese fenomeen wyer was as 
wat voorheen vermoed is - nie net in Mari en die Nieu-Assiriese ryk wat onder WesSemitiese invloed gestaan het, nie, maar ook in die koninkryk van Eshnunna 88 . Volgens die huidige stand van inligting kan gesê word dat die Ou-Testamentiese profesie van die Ou-Nabye Ooste veral ten opsigte van die volgende verskil:

a) Wat die adressate van die profetiese boodskap betref: in die wyere $\mathrm{Ou}$ Nabye Ooste word dit byna uitsluitlik aan die koning gerig. Daar is op die oomblik uit Mari net een teks bekend waar die inwoners van 'n sekere geografiese gebied die aangesprokenes is 89 . Daarteenoor vind ons dat in die Ou Testament in die opsig 'n sekere "demokratisering" plaasvind: waar die adressaat in die vroeg-monargale tyd nog die koning was, word dit in die tyd van die "klassieke" profesie (agste eeu en later) byna uitsluitlik die volk.

b) Wat die aard en inhoud van profesie aangaan: in die Ou Nabye Ooste was dit situasiegebonde en is nie weer in nuwe omstandighede geaktualiseer nie. In Israel, egter, het dit in literêre tradisies neerslag gevind en het dit in die lig van veranderde tye "gegroei" en nuwe toepassings gevind ${ }^{90}$. Wat die inhoud betref is die Ou-Nabye Oosterse profesie uitsluitlik heilsprofesie. Dit is gerig op die voorspoed en sukses van die koningshuis. 'n Onvoorwaardelike gerigsaankondiging, soos in die Ou Testament die geval is, is vreemd aan die Ou-Nabye Oosterse profesie. Ook die universele etiese appél wat in die verband in die Ou Testament gemaak word, is uniek. Saggs, wat juis andersins wys op die gemeenskaplikhede tussen Israel en Mesopotamië, verwoord dié eiendomlikheid soos volg: "Never in any circumstances did the message of the Mesopotamian ecstatic break through these bounds to give a message not to a man, but to Man, not merely about the behaviour demanded from a particular man in a particular situation, but about the behaviour demanded from mankind, not about the intentions of the gods for the immediate circumstance, but about God's very nature"91.

SLOTOPMERKING

Uit hierdie algemene oorsig met betrekking tot huidige tendense in die profetiese navorsing blyk duidelik dat daar nog heelwat onbeantwoorde vrae is en dat ook baie sekerhede, wat vir 'n lang tyd met betrekking tot die profete gegeld het, weer krities onder die vergrootglas gehou moet word. Ward het reg as hy die volgende sê: "... the story of contemporary prophetic studies is an unfinished story. The contents of the next chapter are quite uncertain"92.

\section{NOTAS:}

1 Die finansiële bystand gelewer deur die Sentrum vir Wetenskapontwikkeling 
(RGN, Suid-Afrika) en die Stichting Studiefonds voor Zuidafrikaanse Studenten vir hierdie navorsing wat gedurende Januarie-Julie 1993 in Leiden en Tübingen plaasgevind het, word hiermee erken. Menings uitgespreek en gevolgtrekkings waartoe geraak is, is dié van die outeur, en moet nie noodwendig aan die twee instellings toegeskryf word nie.

2 Vir'n algemene oorsig oor die literatuur wat tot in die sewentigerjare in veral Duitsland verskyn het, vergelyk P H A Neumann, Das Prophetenverständnis in der deutschsprachigen Forschung seit Heinrich Ewald, Darmstadt 1979, 1-51. Vir meer resente literatuur, vergelyk J Blenkinsopp, $A$ history of prophecy in Israel, Philadelphia 1983 en H D Preuss, Theologie des Alten Testaments, Band 2, Stuttgart 1992, 72-104.

3 R P Carroll, When prophecy failed: cognitive dissonance in the prophetic traditions of the Old Testament, New York 1973.

4 R R Wilson, Prophecy and society in Ancient Jsrael, Philadelphia 1980.

5 D L Petersen, The roles of Israel's prophets, Sheffield 1981.

6 T W Overholt, Prophecy in cross-cultural perspective: a sourcebook for biblical researchers, Atlanta 1986; idem, Channels of Prophecy: the social dynamics of prophetic activity, Minneapolis 1989.

7 G Fohrer, "Remarks on the modern interpretation of the prophets", $J B L 80$ (1961), 309.

8 H M Barstad, The religious polemics of Amos, Leiden 1984, 1.

9 F E Deist, "The prophets: are we heading for a paradigm switch?", in: Prophet und Prophetenbuch. Festschrift für Otto Kaiser zum 65. Geburtstag (hrsg V Fritz et al), Berlyn 1989, 1-18.

10 W A Ward, "The eclipse of the prophet in contemporary prophetic studies", USQR 42 (1988), 97-104.

11 W Gross, "Prophet gegen Institution im Alten Israel?", $T h Q 171$ (1991), 16.

12 K F Keil, Lehrbuch der historisch-kritischen Einleitung in die kanonischen und apokryphischen Schriften, Frankfurt a. M. 1859, 194.

13 H Ewald, Jesaja mit den übrigen älteren Propheten, Göttingen 1867, 6.

14 D L Petersen, Late Israelite prophecy, Missoula 1976, 2.

15 Preuss, $a w, 73$, wat hom hier beroep op J Jeremias, THAT II, 8.

16 J Barton, Oracles of God, London 1986, $1 \mathrm{ev.}$

17 O Kaiser, Der Gott des Alten Testaments. Theologie des AT I: Grundlegung, 
Göttingen 1993, 329 ev.

18 J Jeremias, "Grundtendenzen gegenwärtiger Prophetenforschung", Der Evangelische Erzieher 36 (1984), 7.

19 G Krause, Studien zu Luthers Auslegung der kleinen Propheten, Tübingen $1962,295$.

20 B Duhm, Israels Propheten, Tübingen 1916, 8.

21 J Becker, "Historischer Prophetismus und biblisches Prophetenbild", in: Die alttestamentliche Botschaft als Wegweisung. Festschrift für Heinz Reinelt (hrsg J Zmijewski), Stuttgart 1990, 15.

22 C T Begg, "The classical prophets in the chronistic history", BZ 32 (1988), 100-107; R. Then, "Gibt es denn keinen mehr unter den Propheten?" Zum Fortgang der alttestamentlichen Prophetie in frühjüdischer Zeit, Frankfurt a M 1990.

23 B Lang, "Prophetie", in: Neues Handbuch theologischer Grundbegriffe, 4 (hrsg P Eicher), München 1991, 307.

24 R Meyer, $T W N T$, VI, 828.

25 H Utzschneider, Künder oder Schreiber?" Eine These zum Problem der "Schriftprophetie" auf Grund von Maleachi 1,6-2,9, Frankfurt a.M. 1989; idem, "Die Schriftprophetie und die Frage nach dem Ende der Prophetie", $Z A W$ 104 (1992), 377 ev.

26 H Donner, "Forscht in der Schrift Jahwes und lest!" Ein Beitrag zum Verständnis der israelitischen Prophetie, ZTK 87 (1990), 295.

27 D E Aune, Prophecy in early Christianity and the ancient Mediterranean world, Grand Rapids 1983.

28 Lang, $a w, 310$.

29 F Stolz, "Propheten, Prophetie", in: Evangelisches Kirchenlexikon, Göttingen $1992,1336$.

$30 \quad$ Meippert, "Aspekte israelitischer Prophetie im Lichte verwandter Erscheinungen des Alten Orients", in: Ad bene et fideliter seminandum. Festgabe für K Deller, Neukirchen-Vluyn 1988, 289f.

31 Vergelyk Utzschneider, ZAW 104 (1992), $377 \mathrm{ff}$.

32 E Fascher, Prophetes. Eine sprach-und-religionsgeschichtliche Untersuchung, Giessen 1927, 51.

33 R Rendtorff, $T W N T$, VI, 796. 
34 R P Carroll, "Night without vision: Micalh and the prophets in the scriptures and the scrolls", VTS 49 (1992), 84. Vergelyk ook A G Auld ("Prophecy in Books: A Rejoinder", JSOT, [48], 1990, 32) wat min of meer dieselfde te sê het oor die profetiese titel: "...it is much less immediate and much more filtered and imaginative and literary".

35 J Jeremias, "Amos 3-6. Beobachtungen zur Entstehungsgeschichte eines Prophetenbuches", ZAW 100 (1988), 124.

36 J Barton, "Early christian prophecy" in: The Anchor Bible Dictionary, 5 (ed. D N Freedman), New York 1992, 496.

37 Barton, $a w, 13$.

38 N Greinacher, "Der Schrei nach Gerechtigkeit in Latein-Amerika. Die prophetische Dimension der Theologie der Befreiung", ThQ 170 (1990), 116.

39 W Brueggemann, The prophetic imagination, Philadelphia 1978, 11-27, 44-61, $62-79$.

40 K Barth, Kirchliche Dogmatik III/4, Zürich 1951, 584.

41 N K Gottwald, The Hebrew Bible. A socio-literary introduction, Philadelphia $1985,28$.

42 Gottwald, ibid, 307.

43 Blenkinsopp, $a w, 31 \mathrm{ev}$.

44 E E Evans-Pritchard, Nuer Religion, Oxford 1956, 303ev en I M Lewis, Ecstatic Religion, Harmondsworth 1971.

45 K Burridge, New heaven new earth: A study of millenarian activities, New York $1969,154 \mathrm{ev.}$

46 Wilson, $a w$.

47 Vergelyk die aangehaalde werke in voetnoot 6.

48 M D Carroll, Contexts for Amos, Sheffield 1992, 35.

49 C S Rodd, "On applying Sociological Theory", JSOT 19 (1981), 105.

50 G Fleischer, Von Menschenverkäufern, Basankühen und Rechtsverkehren, Frankfurt a M 1989.

51 R Kessler, Staat und Gesellschaft im vorexilischen Juda: vom 8. Jahrhundert bis zum Exil, Leiden 1992.

52 Carroll, $a w, 82$. 
53 T R Hobbes, "The search for prophetic consciousness. Comments on Method", BTB 15 (1985), 137.

54 Hobbes, ihid, 138.

55 G A Herion, "The impact of modern and social science. Assumptions on the reconstruction of Israelite History", JSOT 34 (1986), 11.

56 R Rendtorff, "Die Entstehung der israelitischen Religion als religionsgeschichtliches und theologisches Problem", in: Gesammelte Studien zum Alten Testament, München 1975, 134.

57 H Ringgren, Israelitische Religion, Stuttgart 1963; T C Vriezen, De godsdienst van Israël, Zeist 1963; G Fohrer, Geschichte der israelitischen Religion, Berlyn 1969.

$58 \quad$ L Perlitt, Vatke und Wellhausen, Berlyn 1965, 119.

59 M D Coogan, "Canaanite origins and lineage: reflections on the religion of Ancient Israel", in: Ancient Israelite religion: essays in honor of Frank Moore Cross (ed P D Miller et al), Philadelphia 1987, 115-124.

$60 \quad$ N Lohfink, "Ein Wolkenspalt", JBT 7 (1992), $397 \mathrm{f}$.

61 R Albertz, Religionsgeschichte Israels in alttestamentlicher Zeit, Göttingen $1992,41$.

62 M Smith, Palestinian parties and politics that shaped the Old Testament, London 21987, 23.

63 Freiburg 1992.

64 Becker, $a w, 14$.

65 Becker, ibid, 12.

66 N P Lemche, Ancient Israel: a new history of Israelite society, Sheffield 1988, 8.

67 R Rendtorff, Kanon und Theologie, Neukirchen-Vluyn 1992, 70.

68 C Dohmen, "Es geht um das Ganze. Aktuelle Tendenzen in der alttestamentlichen Wissenschaft", Herder Korrespondenz 46 (1992), 86.

69 M Nissinen, Prophetie, Redaktion und Fortschreibung im Hoseabuch, Neukirchen-Vluyn 1991, 338. Vergelyk ook Kaiser $(Z A W$ 104, [1992], 452) se positiewe reaksie op die studie.

70 T Naumann, Hoseas Erben. Strukturen der Nachinterpretation im Buche Hosea, Stuttgart 1991, 155. 
71 A H J Gunneweg, Biblische Theologie des Alten Testaments, Stuttgart 1993, 177.

72 K Budde, Die Religion des Volkes Israel bis zur Verbannung, Giessen 1900, 14.

73 Vergelyk hier veral die twee mees resente studies van Weippert, $a w$, en Nissinen, "Die Relevanz der neuassyrischen Prophetie für die alttestamentlichen Forschung", in: Mesopotamica-Ugaritica-Biblica. Festschrift für Kurt Bergerhof, Neukirchen-Vluyn 1993, 217-258.

$74 \quad$ Kyk hier veral Neumann (voetnoot 2) met uitvoerige literatuur en Weippert (voetnoot 30 ) wat die stand tot in die tagtiger jare gee.

$75 \quad \mathrm{M}$ de J Ellis, "Observations on Mesopotamian oracles and prophetic texts", JCS 41 (1989), 132. Kyk ook E Noort, Untersuchungen zum Gottesbescheid im Mari, Neukirchen-Vluyn 1977, 9-34.

76 Sien Weippert, a w, $291 \mathrm{ev}$, vir voorbeelde.

77 Vir die onderskeid tussen induktiewe en intuitiewe profesie, kyk M Dietrich, "Prophetie in den Keilschrifttexten", Jahrbuch für Anthropologie und Religionsgeschichte 1 (1973), 16 ev.

$78 \quad$ Nissinen, $a w, 221$.

79 J-M Durand, Archives epistolaires de Mari 1/1, Parys 1988, 444-445.

80 H B Huffmon, "Ancient Near Eastern prophecy", in: The Anchor Bible Dictionary (editor D N Freedman), New York 1992, 479.

81 O Kaiser, Das Buch des Propheten Jesaja: Kapitel 1-12, Göttingen 51981, 19.

$82 \quad$ H Ringgren, VTS 40 (1986), 206.

83 H-J Zobel, "Die Anfănge des Prophetentums im Alten Testament", in: Von Bileam bis Jesaja (hrsg G Wallis), Berlyn 1987, 32.

$84 A w$.

85 A Malamat, "A forerunner of Biblical prophecy: The Mari documents", in: Festschrift Cross (voetnoot 59), 33-52.

$86 A w$.

$87 A w$.

$88 \quad$ M de J Ellis, "The goddess Kititum speaks to king Ibalpiel: Oracle texts from Ishichali", MARI 5 (1987), 235-266. Vergelyk ook Nissinen, $a w, 223 \mathrm{f}$.

89 Huffmonn, $a w, 479$. 
90 Nissinen, $a w, 249$. Kyk ook F Nötscher, "Prophetie im Umkreis des Alten Israel", $B Z N F 10$ (1966), 16 l-197.

91 H F W Saggs, The Encounter with the divine in Mesopotamia and Israel, London 1978, $151 \mathrm{ev}$.

92 Ward, $a w, 104$. 